EASTERN REVIEW 2020, T. 9

\author{
Anna Jach \\ (iD) https://orcid.org/0000-0002-3748-5406 \\ Jagiellonian University, Cracow, Poland \\ Faculty of International Studies and Political Studies \\ Institute for Russian and Eastern European Studies \\ e-mail: anna.jach@uj.edu.pl
}

\title{
Possibilities for cooperation between the non-governmental, non-commercial sector and the public sector in modern Russia*
}

\begin{abstract}
The model of three-sector synergy in a contemporary state rests on cooperation between the first (state) sector, the second (commercial) sector, and the third sector - the civil one, also referred to as the non-commercial sector. The quest for an optimal solution and the establishment of mutual relations is underpinned by the concept of the reorganization of Russian society with regard to its political modernization; this is accompanied by a variant of social agreement that guarantees citizens equality before the law, and the protection of their rights along with simultaneous compliance with the law. What complements the image of Russia's contemporary reality is the goal of non-governmental, non-commercial organizations - not only to survive but also to develop a modus vivendi in the circumstances of an authoritarian state.
\end{abstract}

Keywords: Russia, non-governmental, non-commercial sector, society's modernization, cooperation, inter-sectoral synergy.

The concern over the survival of civil society institutions is expressed not only by the citizens themselves, directly interested in this issue, but also by the representatives of the business environment and the state's authorities, both at the central and territorial level. Thanks to the interest expressed by the academic

* This article on the possibilities of cooperation between the non-governmental, non-commercial sector with the state sector in contemporary Russia (i.e. a state undergoing transformations whose vector is as yet unspecified) is an abbreviated version of a section of the book published by Anna Jach (2019). 
and scientific centres (think tanks), in the issues related to effective management in the 21st century, Russian politics witnessed the development of the most optimum variant of three-sector synergy, which is to result in an increase in the efficiency of the functioning of the state's structures. The following article discusses the conditions and potential for cooperation between the state, private, and non-governmental, non-commercial sectors in contemporary Russia.

\section{Introduction}

The model of three-sector synergy in a contemporary state rests on cooperation between the first (state) sector, the second (commercial), and the third one - the civil sector, also referred to as the non-commercial sector. The possibility of cooperation between the three pillars of a contemporary, modern state should be based on the principle of balance, yet explicit parity is not the case here. The literal equality of the three sectors is impossible due to the scope of their influence related to their core functions. The question which should be addressed regards the nature of this cooperation, particularly in circumstances where the consolidation of the state's political system is still an ongoing process.

Since it was assumed that the state's structures cannot function when isolated from the other two sectors - commercial and non-governmental structures and political organizations - the decision which followed was to develop an individual model of cooperation between these three sectors of the political system. The fulfilment of certain state functions is only possible when there is balanced interaction between its participants. In such circumstances, policy-makers were forced to re-establish relations with these entities which are the core of civil society - the non-governmental, non-commercial organizations.

The conditions which more precisely determine cooperation between the state, business and non-governmental, non-commercial organizations, understood as an emanation of civil society in contemporary Russia, can be traced when looking at tasks assigned to the two of them - the state and civil society organizations. The nature of their mutual relations can be discerned in the following principles:

1) state registration, regulation of legal grounds for cooperation;

2) the indication of the areas in which non-governmental, non-commercial sector organizations would be vitally interested in getting involved;

3) the elimination of the premises hindering the development of cooperation;

4) the establishment of inter-mediatory structures for cooperation;

5) the definition of the methods and forms of cooperation of the non-governmental, non-commercial sector with state structures.

The assumption underpinning this model of cooperation is the concept of the reorganization of Russian society in the context of its political modernization, 
accompanied by a variant of a social agreement that guarantees the citizens equality before the law and protects their rights, while respecting the law. On the other hand, based on their previous experience (successes, failures, problems in the cooperation between society and non-governmental organizations; and non-governmental organizations and the state; as well as non-governmental organizations and business), representatives of the civil sector developed optimal mechanisms for cooperation with other entities of Russian civil society, which are designed to ensure not only the survival of NGOs in the non-profit sector, but also the implementation of tasks and fulfilment of the functions for which they were established by their founders. The awareness of the complexity of the position of the social sector in Russia resulted, and still stems, from its dependence on the political will of the policy-makers, who - contrary to the widely proclaimed postulates constituting the quintessence of civil society - are far from making both the commercial and non-commercial sector equal to the state sector. They allow some freedom of civil activity, as long as such does not endanger not only the vital interests of the ruling elite, but also the reserved sphere of political management.

In contemporary conditions, a state's functioning focuses around a primary state-centric goal and assumes control of interactions between an individual, the society and the state because both social structure and the condition of the legal organization of social life depend to a great extent on achieving this goal. Adopting the "national interests of the Russian Federation" as the entirety of the internal and external needs of the state with a view to ensuring the safety and sustainable development of an individual, the society and the state (Ukaz Prezidenta Rossijskoj Federacii "O strategii nacional'noj bezopasnosti...", 2009), forced the policy-makers to develop their own model of cooperation between the three sectors of the political system. This in turn necessitated activities aimed at raising citizens' legal awareness, according to the guidelines set in the policy of the modernization of Russian politics and statehood. Speaking about coordinating or harmonizing the interests of an individual, the society and the state, a priority task focused on developing a model of state laws; what the rulers actually had in mind was a project concerning society's modernization (Kertman, 2007: 120). Its foundation became the version of the social contract in which the state ensures that its citizens are equal before the law and that their rights are protected; in turn, the citizens abide by the law, solving their problems not with bribes or other illegal means but by using legal mechanisms (Osnovy gosudarstvennoj politiki Rossijskoj Federacii..., 2011; Shhuplenkov, Shhuplenkov, 2013: 1-55). 


\section{State registration}

One of the forms of cooperation between the state and the society in contemporary Russia, with regard to the procedure of legitimizing legal entities and non-governmental organizations is state registration. This has been of great interest to other entities involved in cooperation with a public partner, as well as other natural or legal persons interested in various forms of participation in the society and state as a whole. If the foundation of such cooperation is to be a model based on the social contract concluded between the government and the society, which implicates the mutual duties of both parties and the full responsibility of the government before its citizens, then then development and implementation of a procedure for controlling the activities of non-governmental organizations has become an urgent issue (Polnyj tekst vystuplenija Dmitrija Medvedeva..., 2008). This is particularly the case in light of the large number of unregistered nonprofit structures with shadowy financing (Kozhevnikov, 2012: 194; Zakljuchenie na proekt federal'nogo zakona..., 2005). Local and foreign experiences with implementing registration and control procedures for organizations of the non-commercial or non-governmental sector, were used during the preparations for the introduction of the Unified State Register of Legal Entities (Yedinyy gosudarstvennyy reyestr yuridicheskikh lits - YEGRYU/the USRLE) (Federal'nyj zakon “O gosudarstvennoj registracii...", 2018). As a result, the cooperation forms were classified as the following models:

- the liberal model (razreshitel'naya model') (characteristic for imperial Russia in its post-absolutist period, showed signs of quite an open - to wit, liberal - approach to the institutions of the emerging civil society in the second half of the 19th c. and in the early 20th c.) (Svod zakonov Rossijskoj imperii..., 1857: 425-438);

- registration by declaration (registratsiya zayavitel'naya, uvedomitel'naya) - characteristic for the USA during the period of monopolist capitalism and the emergence of post-industrial society as well as for Russia after 2000 (Kozhevnikov, 2012: 200-201);

- the safe model (yavochnaya model') - a very simplified procedure leads to balancing the interest of the general public with the freedom to create new legal entities, adopted in Germany and the United Kingdom (Companies House);

- the administrative model (rasporyaditel'naya model') - a legal entity is created solely through its founder's decision while an organization does not require state registration - tsarist Russia, the USSR, the RF (Ugolovno-ispolnitel'nyj kodeks Rossijskoj Federacii, 1997; Popechitel'noe o tjur'mah obshhestvo, 1890-1907: 546-547; Kozhevnikov, 2012: 206).

In the wake of legal solutions regulating these two spheres of cooperation, the policy-makers split the general state registration procedure into the 
general registration procedure for legal entities (registration of all commercial organizations) and the special registration procedure for legal entities (registration of non-profit organizations, civic associations, mass transport institutions, credit unions, religious organizations and a number of other legal entities). This led to the development of detailed criteria describing the documents required for registration, its special time limits and the registration refusal procedure; the criteria took into consideration the differences existing, in terms of the status of legal entities, between those wishing to form entities of the non-governmental, non-commercial sector and the institutions authorized to perform registration. This became the basis for developing guidelines for various legal and organizational types of entities in the Russian third sector that prescribed the rules of cooperation between the state and the social sector; unfortunately, the guidelines increase the legal chaos surrounding the state registration procedure. Furthermore, its implementation was tasked to two different state bodies - the Ministry of Justice of the Russian Federation (RF) with its regional branches (Ukaz Prezidenta RF "Voprosy Ministerstva justicii Rossijskoj Federacii", 2004) and the Federal Tax Service of the RF (Federal'naja nalogovaja sluzhba). The question remains which organs will be held accountable for violating the state registration regime. When this function is assigned to two separate authorized government bodies, it turns out that such a division of accountability de facto fully corresponds to the powers assigned by the lawmakers both to the Ministry of Justice and the Federal Tax Service with regard to fulfilling the function of institutions responsible for registration itself, as well as for entering relevant information into the Unified State Register of Legal Entities (Postanovlenie Pravitel'stva RF..., 2006; Prikaz Minjusta Rossii..., 2012).

\section{The subject of the governance process}

The characteristic features of the non-governmental, non-commercial sector in this respect make such entities a peculiar institution. The difference between commercial and non-commercial organizations as to their products - both material (goods and services) and immaterial (health products, good mood, acceptance of spiritual values by people, social objectives) - is irrelevant in the case of state corporations. Running non-profit activities does not mean a negative attitude towards the business sphere. As the social sector is one of the most dynamically developing sectors of social economy both in Russia and in the wider world, its structures can assign their profits for their own statutory purposes. Pointing out the existence of the two subjects of the governance process - the needy and the donors (funders) (Tul'chinskij, Shekova, 2009: 36), where it is impossible to determine which of them appeared first, 
was a reference to the theory of governance adopted in other states with regard to the non-commercial sphere. In public goods production theory (teoriya "proizvodstva obshchestvennykh blag"), the instruments of administering the non-governmental, non-commercial sector include social marketing, fundraising and volunteering. Referring to the elements of the earlier concept, the contract failure theory (teoriya "nevypolnennogo kontrakta") supplements it by introducing limitations in the distribution of the profit of non-commercial organizations; with an obligation to channel the profit into primary business activity, and control over the distribution of the profit of a non-commercial organization in the society. The last governance theory, the stakeholder control theory (teoriya "kontrolya steykkholderov") (Jach, 2019: 309-314), influences the non-governmental civil sector by means of stakeholders exercising control over the activities of non-commercial formations through establishing boards of trustees (popechitel 'skiy sovet) for particular social structures (Federal'nyj zakon “O nekommercheskih organizacijah", 1996; Shekova, 2014: 250-251). Russian institutions where the methods and means of managing the non-governmental, non-commercial sector have been successfully applied are the State Hermitage Museum (Tul'chinskij, Shekova, 2009: 46; Shekova, 2014: 248-250), the State Russian Museum in Sankt Petersburg and the State Tretyakov Gallery in Moscow (Shekova, 2003: 40). After the successful implementation of remedial actions, these two cultural and scientific institutions of special standing not only emerged from a state of collapse but also began to support other non-profit institutions, in particular cultural and scientific ones (Ukaz Prezidenta Rossijskoj Federacii “O dopolnitel'nyh merah...", 1999; Popechitel'skie sovety: stanovlenie, razvitie, opyt...). One of many peculiarities, in this case, is that this important and successful experiment has not been widely publicized in Russia; this is due to the deeply rooted conviction that the dominant role in this sphere belongs to the state, which is not going to compete with other subjects in this field.

\section{State control}

Public authorities acting as controllers is an inherent element of public administration; its efficiency determines in advance the effectiveness of the state in performing duties assigned to its governing bodies. As an important characteristic of the non-governmental, non-commercial sector is the level and dynamics of the development of civil society; to that end lawmakers defined its constitutional principles regarding bringing the third sector under state control:

The universal rules include the following: the principle of legality (printsip zakonnosti) and proportionality (printsip sorazmernosti). 
In turn, the canon of the so-called special rules consists of the following: funktsii);

1) the principle of control function unity (printsip yedinstva kontrol'noy

2) the principle of completeness and of horizontal and vertical division of control rights in accordance with the constitutional beginning of organization of public government in the RF (printsip polnoty i raspredeleniya kontrol'nykh polnomochiy po gorizontali i vertikali soobrazno konstitu);

3) the principle of the balanced ensuring of basic rights and competences on which the rule of law is founded (printsip sbalansirovannogo obespecheniya osnovnykh i kompetentsionnykh prav, kotoryy, yavlyayas'fundamental);

4) the principle of coherence (printsip sistemnosti);

5) an unacceptability of interference in the activities of the controlled subject (printsip nedopustimosti vmeshatel'stva kontroliruyushchego organa $v$ operativnuyu deyatel 'nost' proveryayemogo);

6) the principle of presuming the goodwill of the controlled subjects (printsip prezumptsii dobrosovestnosti kontroliruyemykh sub'yektov);

7) the principle of rationality (printsip ratsional'nosti);

8) the principle of transparency (printsip transparentnosti) (Kozhevnikov, 2012: 239-245).

The fact that the Russian reality does not adhere to the above norms can be seen in many legal regulations published by the Ministry of Justice of the Russian Federation, which, alas, has not found any application for these principles. This leads to a conclusion that there is a gap between the letter and the spirit of the law, which is reflected in the practical application of the norms defining not only the functioning of the Russian civil sector but also that of the two other sectors, the public and the private, which are closely connected with the former. The situation reveals the blatant arbitrariness and, consequently, instability of Russian legislation, which is entirely dependent on the political elites currently in power. The lack of the stability of the broadly defined social system leads in practice to the worsening dysfunction of all the other subsystems: the political, civil, economic and religious ones.

As regards state control over the non-governmental, non-commercial sector, the Russian legislature provides for the supervision of finances and statistical reports, as well as of current activities; the legality of which is analysed on the basis of a given entity's instruments of incorporation (Prikaz Ministerstva justicii Rossijskoj Federacii “Ob utverzhdenii Admini-strativnogo reglamenta...”, 2011). Institutions responsible for the state supervision of the third sector in Russia do so through the use of the following tools:

1) control of non-commercial organizations' activities (Kontrol' $z a$ dejatel'nost'ju...; Plan proverok...; Prikaz Ministerstva justicii Rossijskoj Federacii “Ob utverzhdenii Administrativnogo reglamenta...", 2011; Edinyj portal gosudarstvennyh uslug i funkcij (EPGU)); 
2) procedure of auditing non-profit organizations (Provedenie proverok...; Federal'nyj zakon “Ob osnovnyh garantijah izbiratel'nyh prav...", 2002);

3) analysis of the control subject (an organization) directly related to the characteristics of this formation; and analysis of activities directly related to spending funds and using property, in terms of compliance with the objectives defined in the instruments of incorporation (Charykova, 2018; Federal'nyj zakon "O buhgalterskom uchete", 2011; Ukaz Prezidenta RF "Voprosy Ministerstva justicii Rossijskoj Federacii", 2004; Prikaz Ministerstva justicii Rossijskoj Federacii "Ob utverzhdenii Administrativnogo reglamenta...", 2011; Federal'nyj zakon "O nekommercheskih organizacijah", 1996; Federal'nyj zakon "Obobshhestvennyh ob 'edinenijah", 1995; Federal'nyj zakon "O blagotvoritel'noj dejatel'nosti...", 1995; Federal'nyj zakon "O buhgalterskom uchete", 2011; Ukazanie Banka Rossii..., 2014).

The peculiarity of Russian reality in the sphere of state control over the non-governmental, non-commercial sector can be encapsulated in the statement that an audit is not a simple operation, so a large number of employees are tasked with it. The sluggishness of the control procedure results from ambiguities in legal solutions that are the basis for the establishment and functioning of non-commercial operations. A separate issue is regulations which, contrary to the premises included in the principles, at each stage of administrative cooperation between the civil and the public sector enable the latter to intervene if the authorities demand it. This can directly paralyse a given organization, especially as even the Law "On public associations" authorizes, besides the Ministry of Justice of the RF and its local branches, other bodies that are a part of the bureaucratic apparatus of the Russian Federation: ecology, fire protection and epidemiological services, as well as other services to which the lawmakers assigned supervisory and control functions (Federal'nyj zakon "Ob obshhestvennyh ob'edinenijah", 1995). However, the reorganization of this sphere of NGOs' activity brought also positive results: their registers are kept correctly, and their expenditures and other assets are used in compliance with the statute objectives set in the documents of incorporation.

\section{Spheres of activity of the non-governmental, non-commercial sector}

The main areas within which civil organizations fulfil their tasks, as declared in the mission and objectives included in their documents of incorporation, remain the following spheres of activity: social assistance (to the homeless, the disabled and the social groups incapable in dealing with life); socio-cultural activities (science and education; culture; leisure); human rights protection (legal aid, prevention); historically oriented and military-patriotic activities (reviving the memory of past events through competitions, school contests and tournaments, presentation of 
historic events by reenactment groups); activities focusing on ecological issues and environmental protection (social campaigns for saving endangered species of fauna and flora; countermeasures against the threats resulting from nuclear energy use); activities focusing on children and youth (orphans, adoption processes, domestic violence prevention); activities focusing on health service, health protection, and the prevention of health problems (screening tests and related information meetings, health awareness campaigns).

There are of course a multitude of factors that can influence the emergence of the non-governmental, non-commercial sector, including but not limited to: the role they can fulfil; involvement of Russian citizens in the activities of NGOs; the balanced three-sector model of a modern state; expectations of different bodies regarding the duties of both the public and the civil sector; the role of individuals in the process of the emergence or functioning of a civil society; and the typology of legal and organizational forms of NGOs. When considering the aforementioned peculiarities, it is possible to make a synthetic presentation both of the functions fulfilled by non-governmental, non-commercial organizations and of their modus operandi types. Such functions of the non-governmental, non-commercial sector as affiliative, expressive, aid (functions related to satisfying needs, interests and demands of associated persons), integrative, childcare and educational, regulatory, lobbying and society-building (functions related to fulfilling the needs of broader communities) are accompanied by specific basic types of modus operandi (Gliński, 2006: 51-260). The latter include such models as third-sector (Gliński, 2006: 52-53), leadership (Gliński, 2006: 99; Wierzchosławski, 2006: 82-109), nostalgic, "convert" (Gliński, 2006: 152; Klejmjonova, 2005), phantom (Gliński, 2006: 159-160; Antoszewski, 2003: 53), dispersive citizens' enclaves (Putnam, 1995: 258-275; Sojuz blagotvoritel'nyh organizacii...; Larichev, Batalin, 2017; Timofeev, Gogolev, 2012), para-political (Komarov, Mal'ko, 2004: 157; Public Policy Research..., 2017; Hasmath, Hildebrandt, Hsu J., 2019: 4-5; Cook, Vinogradowa, 2006: 14; Molodezhnye politicheskie organizacii Rossii, 2010), symbiotic (Gliński, 2006: 211), business (Gliński, 2006: 233; Zakon RF "O potrebitel'skoj kooperacii...", 1992; Federal'nyj zakon "O kreditnoj kooperacii", 2009; Chto takoe kreditnyj potrebitel'skij..., 2018; Gosudarstvennyj reestr...) or communal ones (Siellawa-Kolbowska, 2002: 82; Putnam, 2008: 40; Grootaert, Van Bastelaer, 2002: 2; Gliński, 2006: 244-245, 260).

\section{Factors hindering the development of cooperation between the non-governmental, non-commercial sector and the state}

The obstacles to the emergence of a partnership-based civil society result either from the institutional and structural weaknesses of the state (exogenous obstacles) or from the weaknesses of the self-organizing society (endogenous 
obstacles). They lead to the atrophy of the very idea of political representation, the source of which are mental barriers regarding the perception of actors on the political stage. The foundation of transformations in this sphere is social capital, which - as a factor determining social activity - is a key to understanding civil society, its institutions and the character of actions undertaken in its sphere (Marody, 2011: 439; Masłyk, 2007: 127). Among a number of problems hindering cooperation between the non-governmental, non-commercial sector and the state there are obstacles of an organizational, legal, financial, personnel (including the person of the leader), communication/information and mental nature. Their classification was possible because the functioning of the third sector in Russia has been regularly monitored since the 1990s (Mersijanova, Jakobson, 2007; Mersijanova, 2007; Kozhevnikov, 2012; Sungurov ed., 2002a, 2002b; Maksimova, 2014; Haritonova, 2018).

Although the citizens' behaviour considered by the policy-makers as most desirable during state modernization is the syncretic type of political participation - which means a combination of autonomous, rational, independent and mobilized activity of all citizens - the implementation of this model is hindered by the degree of trust or mistrust towards all representatives of the authorities (Radikow, 2015: 77). This results from the process of differentiation of generations whose interests and expressed issues were directly related to experiences in governance during the past years. What had the greatest impact on the perception of the political system and the society was the experiment of building communism. As a result, in modern Russia, whose inherent feature is transience, there emerged a cultural dissonance within society in the sphere of social values. The symptoms of the realist socialism culture - represented by collectivism, egalitarianism, mediocrity, certainty and security, fate, protectiveness, system blaming, passive privacy and living in the past - were juxtaposed with the values of democratic and market culture: individualism, meritocracy, success, risk, agency, making one's own decisions, public participation and focusing on the future (Sztompka, 2012: 336-337). The overlapping of three axiological systems of Russian society (pre-industrial, industrial and post-industrial) had implications entirely different from those intended, because in many spheres of social life the concepts that served as the basis of the moral evaluation of words and actions of a given person - and which ultimately determined the state's stability - have disappeared. This led to the appearance of factors hindering effective cooperation between the non-governmental, non-commercial sector and the first sector; those detrimental factors included:

a) a perception of politics as a sphere of activity that was alienated from society and belonged to the "ruling elite" and their closest circle (activists and volunteers from political parties, employees of the media, analysts, public relations specialists);

b) the disavowment of the idea that stability had been achieved and of the clear upward trend in all the spheres of social life; 
c) the change of the existing model of citizens' mobilization to one of increased citizen participation;

d) the emergence of informal grassroots self-organization, volunteering and single-postulate movements;

e) young people as active participants of protest movements, vividly reacting to different innovative policy changes;

f) new possibilities of non-political citizens' activities;

g) the nationalization of local self-government as an obstacle to the self-organization of the Russian society at the local level;

h) protest movements being perceived as forms of civil self-organization;

i) the increased participation of virtual communication in organizing citizens' activities (Radikow, 2015: 72-77).

One of the processes of policy and statehood modernization, the clash between the interests of the Russian state and the Russian society, produces a sense of co-responsibility for the common fate, personal benefit, personal interest and the state. Although in the relation of the state and the civil sector it is the former that still has the dominant position; this relation does not reflect a growing asymmetry but rather resembles a striving to develop and maintain a modus vivendi that would guarantee effective state governance, which will result in an increased sense of safety and better living standard for Russian citizens.

The models of interaction between the state and the non-governmental, non-commercial sector in contemporary Russia are the result of traditional relations between the first (public) sector and the third (civil) sector; whilst both originating from the practices of Western and Eastern societies, and recreating local experiences. Thus on the basis of the Western models of the functioning of the third sector (residual, continental, Scandinavian, Mediterranean and that of Central and Eastern Europe), together with organization forms acceptable in these models (Wygnański, Gumkowska, 2005: 112-114; Anheier, Mertens, 2006: 76), Russia developed foundations for these NGOs which undertook the tedious task of satisfying its citizens' social needs. The so-called socially oriented non-commercial organizations (sotsial'no oriyentirovannye nekommercheskie organizatsii - SO NKO) - working in the following fields: social, representation and protection of the socio-economic, political, spiritual-cultural, and information rights of citizens - were considered as bodies of special status. Their position in the structure of the non-governmental, non-commercial sector was marked by separate regulations defining their acceptable legal and organizational forms (with the exception of state corporations, state companies and civic associations which are political parties); their spheres of activity; and the auxiliary regulations regarding the support can receive from the state. The very broad spectrum of SO NKO activities meant that they were entrusted with the tasks of solving the everyday problems neither the state nor municipal authorities were able to cope with (Federal'nyj zakon “O nekommercheskih organizacijah”, 1995; Federal'nyj zakon 
"Ob obshhih principah organizacii...", 1999; Federal'nyj zakon "O zashhite konkurencii", 2006; Kozhevnikov, 2012: 42-48; Federal'nyj zakon "O vnesenii izmenenij $v$ otdel'nye zakonodatel 'nye akty...", 2014).

The concern the Russian policy-makers (e.g. Vladimir Putin) (Poslanie Prezidenta..., 2012; 2013;2014) showed as to whether socially-oriented organizations discharged their duties with due diligence resulted from the state's problems in the area of state governance, leading in turn to its low efficiency. The search for an interaction model optimal for the Russian reality turned to local experiences as well as concepts that could facilitate such a change of the cooperation strategy that would allow the achievement of the intended goals. On the grounds of the social group theory (von Beyme, 2007: 238-241), pluralist approach (Heywood, 2006: 96-98) and neo-corporatism (Galkin, 2000: 148; von Beyme, 2007: 246), it was concluded that the form of cooperation most efficient in Russia is that based on solutions accommodating native conditions. All political actors were considered as specific "corporations", striving to gain access to the decision-making process (Shmitter, 1997: 14); this was accompanied by focusing on the integration of two variations of neo-corporatism that have occurred in Russia: the state (patron-client relations) and the civil one (partner relations). These approaches focused on developing a hierarchical system of relations between the authorities and the civic institutions, which in practice meant that the state maintained a decisive advantage in their mutual relations (Tarasenko, 2015: 36-37).

What turned out to be the key to developing the modus vivendi between the state and the non-governmental, non-commercial sector was the presidential model of governance (the so-called presidential monism) (Jach, 2011: 376; O'Donnell, 1997: 70-72) that emerged during the system transformation and was strengthened further by the post- 2000 centralization of power. As the democratization initiated in 1991 did not end in consolidation, Russia is still considered to be in the process of transition: a transforming state. This means a co-existence of elements from two systems: democratic and authoritarian, which in the hybrid system of governance directly translate into the organization of the mutual relations between the state and the third sector (Noble, 2018; Truex, 2014). This issue has been the focus of the research of different academic groups and universities (the Public Policy Department established by Nina Bielyayeva at the National Research University Higher School of Economics in Moscow - Natsional'nyy issledovatel'skiy universitet "Vysshaya shkola ekonomiki" or the HSE University (Kafedra publichnoy politiki) and by groups of experts (the Saint-Petersburg Centre for Humanities and Political Studies "Strategy", whose president is Alexandr Sungurov - Sankt-Peterburg SPB tsentr "Strategiya" (SPB tsentr "Strategiya"). After numerous debates, joint projects and specialist conferences, the specialists ascertained that the framework for all the forms in which the state fulfils its duties will be the concept of public policy (Solov'ev, 2018: 52), which defined the entirety of the programs and priorities of government bodies as well 
as the mechanisms and technologies employed in their implementation. This was developed on the basis and in consideration of the social expectations of different social groups voiced by their representatives (Sungurov, 2008: 126). Thus the defined concept was used to determine not only the components of public policy ${ }^{1}$ (Sungurov, 2017: 10) but also the sine qua non-condition of its functioning in Russian reality.

\section{Conclusions}

Defined on the basis of strictly Russian conditions, the models and forms of cooperation between the non-governmental, non-commercial organizations and the state administration correspond to the development of the contemporary civil society. Including both the historical perspective and the transformations of the citizens' perception of the functionality of the Russian state and society, it can be concluded that firstly, the civil society (understood as the organizations of the non-governmental, non-commercial sector) cannot exist entirely independently from the state as it emerges from the state's foundations. Secondly, the state influence the activity of the civil society institutions; this involves mainly ensuring the optimal conditions for their effective functioning. Simultaneously, the civil society institutions are also able to influence the activities of the state in order to achieve significant results, represent the interests of citizens, and protect their rights and freedoms. Thirdly, the current situation in Russia is only a stage in the development of relations between the state and the civil society institutions.

1 Defining the term "public policy", when it first appeared, was problematic within Russian political science. There existed concomitantly such Russian terms as "sotsial'naya politika" ("social policy"), "otkrytaya politika" ("open policy"), and "obshchestvennaya politika" (which can be translated as "public/social policy"). In practice, it was possible to develop one position on the meaning of the term "public policy" (publichnaya politika). One Russian word "politika" corresponds to two, or even three terms in English - politics (struggle for gaining and maintaining power, bor'ba za zavoyevaniye, uderzhaniye vlasti), policy (the development and implementation of political programs by authorities at various levels aimed at solving certain social problems, which can be shortly referred to as "political-managerial activities", razrabotka i realizatsiya programm deyatel'nosti vlasti razlichnogo urovnya, napravlennykh na resheniye tekh ili inykh obshchestvenno znachimykh problem, chto kratko mozhno opisat" kak ,politiko-upravlencheskiye resheniya) and polity (a politically organized community, i.e. "the political world", politicheski organizovannoye soobshchestvo, ili "mir politicheskogo"). The greatest trouble is caused by the first two terms as in practice it resulted in introducing to Russian law such changes as the law on spying, aimed at tracing potential enemies of the state. The branch of political science called in Russia "Gosudarstvennaya (publichnaya) politika" can be translated into English as "state's public policy", i.e. "politika" in its second meaning - a process of making and implementing political decisions regarding management. Vide: Sungurov, 2017: 10. 
Conscious actions of both sides, aimed at developing and strengthening the civil society institutions, should in time result in the increased productivity of their operations (Kolesnikova, Rjabova, 2016: 74).

Seeing the development of the contemporary civil society as a result of agreement and dialogue, one cannot forget, however, that the emerging civil society is unable to adopt the destruction or weakening of the state authorities as its objective. On the contrary, it needs the state, which protects national interests and acts as an arbitrator between various bodies. The quality and variety of discussion platforms between the civil society and the state determine to a great extent the perspectives of further growth of the civil society. Based on this assumption, specialists and researchers from many academic centres, think tanks and expert institutions determined the conditions optimal for cooperation between the non-governmental, non-commercial sector and the government bodies, which predominantly use ways, methods and means provided by the concept of public policy.

\section{References}

Andreevskij, I.E.,Arsen'ev, K.K., Petrushevskij, Ө.Ө.(eds.). 1890-1907. Jenciklopedicheskij Slovar' F.A. Brokgauza i I.A. Efrona (V 86 tomah s illjustracijami i dopolnitel'nymi materialami) T. XXIVa (1898), Sankt-Peterburg, http://www.vehi.net/brokgauz/index. $\mathrm{html}$ (accessed 15.10.2018).

Anheier, H., Mertens, S. 2006. Sektor non-profit w perspektywie międzynarodowej i europejskiej. Dane, teoria i statystyka. In: A. Gałązka, J. Herbst (eds.). Trzeci sektor dla zaawansowanych. Współczesne teorie trzeciego sektora - wybór tekstów. Tłum. J. Popowski. Warszawa: Stowarzyszenie Klon/Jawor, pp. 61-81.

Antoszewski, A. 2003. Grupy interesu w systemie politycznym. In: Z. Machelski, L. Rubisz (eds.). Grupy interesu. Teorie i działanie. Toruń: Wydawnictwo Adam Marszatek, pp. 45-56.

Beyme von, K. 2007. Wspótczesne teorie polityczne. Tłum. J. Łoziński, Warszawa: Wydawnictwo Naukowe Scholar.

Biografija Klejmjonovoj Raisy Nikolaevny. 2011. http://olrs.ru/klemenova.html (accessed 11.06.2018).

Charykova, A.M. 2018. Osobennosti organizacii i provedenija proverok sootvetstvija dejatel'nosti nekommercheskih organizacij, $v$ tom chisle po rashodovaniju denezhnyh sredstv $i$ ispol'zovaniju inogo imushhestva, celjam, predusmotrennym ih uchreditel'nymi dokumentami, http://to19.minjust.ru/ru/node/351768 (accessed 8.11.2018).

Chto takoe kreditnyj potrebitel'skij kooperativ. In: Obshherossijskoe Dvizhenie Kreditnoj Kooperacii. 2018. http://ligaks.ru/3/5/122/chtoestkreditniykooperativ (accessed 12.12.2018).

Companies House. 2018. https://www.gov.uk/government/organisations/companies-house (accessed 31.10.2018). 
Cook, L.J., Vinogradowa, E. 2006. NGOs, Civil Society, and Social Policy in Russia's Regions. Washington D.C.: The National Council for Eurasian and East European Research, https://www.ucis.pitt.edu/nceeer/2006_819_10g_Cook1.pdf (accessed 12.02.2021).

Edinyj portal gosudarstvennyh uslug i funkcij (EPGU), https://www.gosuslugi.ru/ (accessed 8.11.2018).

Fadeev, V.I. (ed.). 2012. Sbornik statej, posvjashhennyh 75-letiju so dnja rozhdenija akademika O. E. Kutafina. Moskva: Izdatel'stvo Jelit.

Federal'naja nalogovaja sluzhba, https://www.nalog.ru/rn77/ (accessed 30.10.2018).

Federal'nyj zakon "O blagotvoritel'noj dejatel'nosti i blagotvoritel'nyh organizacijah" ot 11.08.1995 g. \# 135-FZ (red. ot 5.02.2018), http://www.consultant.ru/document/ cons_doc_LAW_7495/(accessed 8.11.2018).

Federal'nyj zakon “O buhgalterskom uchete” ot 6.12.2011 g. \# 402-FZ (red. ot 29.07.2018), http://www.consultant.ru/document/cons_doc_LAW_122855/(accessed 8.11.2018).

Federal'nyj zakon “ $O$ gosudarstvennoj registracii juridicheskih lic $i$ individual'nyh predprinimatelej" ot 8.08.2001 g. \# 129-FZ (poslednjaja redakcija ot 3.08.2018), http:// www.consultant.ru/document/cons_doc_LAW_32881/(accessed 30.10.2018).

Federal'nyj zakon “O kreditnoj kooperacii” ot 18.07.2009 g. \# 190-FZ (poslednjaja redakcija), http://www.consultant.ru/document/cons_doc_LAW_89568/(accessed 12.12.2018).

Federal'nyj zakon “O nekommercheskih organizacijah” ot 12.01.1996 g. \# 7-FZ (s izmenenijami na 27 ijunja 2018 goda), http://docs.cntd.ru/document/9015223 (accessed 6.11.2018).

Federal'nyj zakon “'O vnesenii izmenenij v otdel'nye zakonodatel'nye akty Rossijskoj Federacii po voprosu podderzhki social'no orientirovanny nekommercheskih organizacij (s izmenenijami na 27 maja 2014 goda)", http://docs.cntd.ru/document/902208260 (accessed 15.07.2018).

Federal'nyj zakon "O zashhite konkurencii" ot 26.07.2006 g. \# 135-FZ (poslednjaja redakcija ot 29.07.2018), http://www.consultant.ru/document/cons_doc_LAW_61763/ (accessed 27.12.2018).

Federal'nyj zakon “Ob obshhestvennyh ob'edinenijah” ot 19.05.1995 g. \# 82-FZ (poslednjaja redakcija), http://www.consultant.ru/document/cons_doc_LAW_6693/ (accessed 8.11.2018).

Federal'nyj zakon “Ob obshhih principah organizacii zakonodatel'nyh (predstavitel'nyh) $i$ ispolnitel'nyh organov gosudarstvennoj vlasti sub'ektov Rossijskoj Federacii" ot 6.10.1999 g. \# 184-FZ (poslednjaja redakcija ot 3.08.2018), http://www.consultant.ru/ document/cons_doc_LAW_14058/(accessed 27.12.2018).

Federal'nyj zakon “'Ob osnovnyh garantijah izbiratel'nyh prav i prava na uchastie v referendume grazhdan Rossijskoj Federacii” ot 12.06.2002 g. \# 67-FZ (red. ot 3.07.2018), http://www.consultant.ru/document/cons_doc_LAW_37119/(accessed 8.11.2018).

Galkin, A.A. 2000. Korporativizm kak forma otnoshenij mezhdu gosudarstvom i obshestvom, Polis. Politicheskie issledovanija 6, pp. 147-158.

Gałązka, A. (ed.). 2005. Elementarz trzeciego sektora. Warszawa: Stowarzyszenie Klon/ Jawor.

Gałązka, A., Herbst, J. (ed.). 2006. Trzeci sektor dla zaawansowanych. Współczesne teorie trzeciego sektora - wybór tekstów. Trans. J. Popowski. Warszawa: Stowarzyszenie Klon/Jawor. 
Gawkowska, A., Gliński, P., Kościański, A. (eds.). 2006. Teorie wspólnotowe a praktyka społeczna. Obywatelskość, polityka, lokalność. Warszawa: Wydawnictwo IFiS PAN.

Gliński, P., 2006. Style działań organizacji pozarzadowych w Polsce. Grupy interesu czy pożytku publicznego? Warszawa: Wydawnictwo IFiS PAN.

Gliński, P., Lewenstein, B., Siciński, A. (ed.). 2002. Samoorganizacja społeczeństwa polskiego. Trzeci sektor. Warszawa: Wydawnictwo IFiS PAN.

Gosudarstvennyj reestr sel'skohozjajstvennyh kreditnyh potrebitel'skih kooperativov, https://www.cbr.ru/finmarket/supervision/sv_micro/ (accessed 12.12.2018).

Grootaert, Ch., Bastelaer van, T. (eds.). 2002. Understanding and measuring social capital - a multidisciplinary tool for practitioners (English). Directions in Development. Washington D.C.: World Bank, http://documents.worldbank.org/ curated/en/221161468741319675/Understanding-and-measuring-social-capital-amultidisciplinary-tool-for-practitioners (accessed 12.11.2018).

Haritonova, E.G. 2018. „Memorial” v Rossii. Vzaimodejstvie gosudarstva i nekommercheskih organizacij $v$ voprosah sohranenija pamjati o zhertvah politicheskih repressij (II polovina 1980-h - nachalo 2000-h gg.). Barnaul: IP Kolmogorov I.A.

Hasmath, R., Hildebrandt, T., Hsu, J.Y.J. 2019. Conceptualizing Government-Organized NonGovernmental Organizations in International Affairs, https://www.researchgate.net/ publication/310766970_Conceptualizing_Government-Organized_Non-Governmental_ Organizations_in_International_Affairs (accessed 11.12.2020).

Heywood, A. 2006. Politologia. Trans. B. Maliszewska. Warszawa: Wydawnictwo Naukowe PWN.

Jach, A. 2011. Rosja 1991-1993. Walka o ksztalt ustrojowy państwa. Kraków: Wydawnictwo Księgarnia Akademicka.

Jach, A. 2019. Pozarzadowy sektor niekomercyjny w Rosji 2000-2018. Osobliwości funkcjonowania. The Non-Governmental, Non-Commercial Sector In Russia in 2000-2018: Peculiarities of Functioning. Nieprawitielstwiennyj niekommierczeskij siektor w Rossii w 2000-2018 gg. Osobiennosti funkcyonirowanija. Kraków: Wydawnictwo Księgarnia Akademicka. DOI: https://doi.org/10.12797/9788381380829

Kafedra publichnoj politiki, https://social.hse.ru/ps/politanaliz/ (accessed 31.12.2018).

Kertman, G.L. 2007. Status partii v rossijskoj politicheskoj kul'ture. Polis. Politicheskie issledovanija 1. DOI: https://doi.org/10.17976/jpps/2007.01.09

Klejmjonova, R.N. 2005. Istorija Obshhestva ljubitelej rossijskoj slovesnosti, http://olrs. ru/obshestvo.html (accessed 11.06.2018).

Kolesnikova, N.A., Rjabova E.L. 2016. Grazhdanskoe obshhestvo v sovremennoj Rossii. Moskva: Mezhdunarodnyj izdatel'skij centr "Jetnosocium".

Komarov, S.A., Mal'ko, A.V. 2004. Teorija gosudarstva i prava. Uchebno-metodicheskoe posobie. Kratkij uchebnik dlja vuzov. Moskva: Izdatel'skaja gruppa "Norma".

Kontrol'za dejatel 'nost'ju nekommercheskih organizacij, http://minjust.ru/ru/press/news/ kontrol-za-deyatelnostyu-nekommercheskih-organizaciy (accessed 8.11.2018).

Kozhevnikov, O.A. 2012. Pravo nekommercheskih organizacij. Uchebnoe posobie. Moskva: Izdatel'sko-torgovaja korporacija "Dashkov i K".

Larichev, A.A., Batalin, A.V. (eds.). 2017. Territorial'noe obshhestvennoe samoupravlenie kak osnova razvitija territorij. Uchebnoe posobie. Petrozavodsk: Karel'skij nauchnyj centr RAN. 
Maksimova, S.G. (ed.). 2014. Social'nyj kapital grazhdanskogo obshhestva. Sostojanie $i$ perspektivy razvitija sektora negosudarstvennyh nekommercheskih organizacij $v$ prigranichnyh territorijah sovremennoj Rossii. Barnaul: IP Kolmogorov I.A.

Marody, M. 1999. Od społeczeństwa drugiego obiegu do społeczeństwa obywatelskiego. Studia Socjologiczne 4(155). In: Studia Socjologiczne 2011, 1(200), pp. 483-499.

Masłyk, T. 2007. Aktywność obywatelska w społeczeństwie informacyjnym. Perspektywa socjologiczna [praca doktorska napisana pod kierunkiem prof. zw. dr. hab. L.H. Habera], mps.

Mersijanova, I.V. 2007. Tretij sektor. Opredelenie, terminologija, granicy, dannye issledovanij $i$ tendencii razvitija. Moskva: Izdatel'skij dom GU-VShJe.

Mersijanova, I.V., Jakobson, L.I. 2007. Negosudarstvennye nekommercheskie organizacii. Institucional'naja sreda i jeffektivnost' dejatel'nosti. Moskva: Izdatel'skij dom GU-VShJe.

Miachelski, Z., Rubisz, L. (eds.). 2003. Grupy interesu. Teorie i działanie. Toruń: Wydawnictwo Adam Marszałek.

Molodezhnye politicheskie organizacii Rossii. 2010. http://rosmolodezh.ru/rosmolodezhfede-ralnoe-agentstvo/rosmolodezh-oficialnye-dokumenty/1237-2010-10-12-13-02-06 (accessed 5.12.2018).

Noble, B. 2018. The Russian parliament is a „,rubber stamp” assembly. But we'd lose a lot by ignoring it, https://medium.com/@bennoble_9433/the-russian-parliament-is-a-rubberstamp-assembly-but-wed-lose-a-lot-by-ignoring-it-862276f7ffba (accessed 29.12.2018).

O’Donnell, G. 1997. Demokracja delegatywna. Res Publica Nowa 4, pp. 66-75.

Osnovy gosudarstvennoj politiki Rossijskoj Federacii v sfere razvitija pravovoj gramotnosti i pravosoznanija grazhdan, utverzhdennye Prezidentom Rossijskoj Fe-deracii 28.04.2011 g. \# Pr-1168, http://minjust.ru/ru/besplatnaya-yuridicheskaya-pomoshch/ osnovy-gosudarstvennoy-politiki-rossiyskoy-federacii-v-sfere (accessed 30.10.2018).

Plan proverok nekommercheskih organizacij. 2018. http://minjust.ru/nko/kontrol/plan proverok (accessed 8.11.2018).

Polnyj tekst vystuplenija Dmitrija Medvedeva na II Grazhdanskom forume v Moskve 22 janvarja 2008 goda. 2008. Rossijskaja gazeta, https://rg.ru/2008/01/24/tekst.html (accessed 30.10.2018).

Popechitel'noe o tjur'mah obshhestvo. In: I.E. Andreevskij, K.K. Arsen'ev, Ө.Ө. Petrushevskij (eds.). 1890-1907. Jenciklopedicheskij Slovar' F.A. Brokgauza i I.A. Efrona (V 86 tomah s illjustracijami i dopolnitel'nymi materialami). T. XXIVa (1898). Sankt-Peterburg, http://www.vehi.net/brokgauz/index.html (accessed 15.10.2018).

Popechitel'skie sovety: stanovlenie, razvitie, opyt (dajdzhest po materialam normativnyh dokumentov, statej i drugih informacionnyh istochnikov), http://sodey.org/assets/images/soveyi.pdf (accessed 29.09.2018).

Poslanie Prezidenta Rossijskoj Federacii Federal'nomu Sobraniju Rossijskoj Federacii ot 12 dekabrja 2012 goda, http://kremlin.ru/events/president/news/17118 (accessed 27.12.2018).

Poslanie Prezidenta Rossijskoj Federacii Federal'nomu Sobraniju Rossijskoj Federacii ot 12 dekabrja 2013 goda, http://kremlin.ru/events/president/news/19825 (accessed 27.12.2018).

Poslanie Prezidenta Rossijskoj Federacii Federal'nomu Sobraniju Rossijskoj Federacii ot 4 dekabrja 2014 goda, http://kremlin.ru/events/president/news/47173 (accessed 27.12.2018). 
Postanovlenie Pravitel'stva RF “O merah po realizacii otdel'nyh polozhenij Federal'nyh zakonov, regulirujushhih dejatel'nost'nekommercheskih organizacij” ot 15.04.2006 g. \# 212 (red. ot 30.05.2013), http://www.consultant.ru/document/cons_doc_LAW_59804/ (accessed 3.11.2018).

Prikaz Ministerstva justicii Rossijskoj Federacii “Ob utverzhdenii Administrativnogo reglamenta ispolnenija Ministerstvom justicii Rossijskoj Federacii gosudarstvennoj funkcii po osushhestvleniju kontrolja za sootvetstviem dejatel'nosti nekommercheskih organizacij ustavnym celjam i zadacham, filialov $i$ predstavitel'stv mezhdunarodnyh organizacij, inostrannyh nekommercheskih nepravitel'stvennyh organizacij zajavlennym celjam i zadacham, a takzhe za sobljudeniem imi zakonodatel'stva Rossijskoj Federacii" ot 30.12.2011 g. \# 456 (red. ot 1.06.2018), http://www.consultant.ru/document/cons_doc_LAW_125298/(accessed 7.11.2018).

Prikaz Ministra Rossii “Ob utverzhdenii Administrativnogo reglamenta predostavlenija Ministerstvom justicii Rossijskoj Federacii gosudarstvennoj uslugi po prinjatiju reshenija o registracii predstavitel'stv inostrannyh religioznyh organizacij $i$ vnesenii svedenij o flialah i predstavitel'stvah mezhdunarodnyh organizacij, inostrannyh nekommercheskih nepravitel'stvennyh organizacij v reestr filialov i predstavitel'stv mezhdunarodnyh organizacij i inostrannyh ne-kommercheskih nepravitel'stvennyh organizacij" ot 28.06.2012 g. \# 122 (red. ot 6.07.2017) (s izmenenijami i dopolnenijami), http://www.consultant.ru/document/cons doc_LAW_132229/2ff7a8c72de3994f30496a0ccbb1ddafdaddf518/(accessed 3.11.2018).

Provedenie proverok nekommercheskih organizacij, http://to29.minjust.ru/ru/provedenie-proverok-nekommercheskih-organizaciy (8.11.2018).

Public Policy Research Think Tanks 2017. Eastern Europe, http://guides.library.upenn. edu/thinktanks2017 (accessed 5.12.2018).

Putnam, R.D. 1995. Demokracja $w$ działaniu. Tradycje obywatelskie we współczesnych Włoszech. Tłum. J. Szacki. Kraków: Wydawnictwo Znak.

Putnam, R.D. 2008. Samotna gra $w$ kręgle. Upadek $i$ odrodzenie wspólnot lokalnych w Stanach Zjednoczonych. Tłum. P. Sadura, S. Szymański. Warszawa: Wydawnictwa Akademickie i Profesjonalne.

Radikow, I. 2015. Polityczna i obywatelska aktywność ludności współczesnej Rosji. Politeja 34/2. DOI: https://doi.org/10.12797/Politeja.12.2015.34_2.06

Richardson, J. (ed.). 1986. Handbook of Theory and Research for the Sociology of Education. Trans. R. Nice. New York: Greenwood.

Schmitter, F. 1997. Neokorporatizm. Polis. Politicheskie issledovanija 2, pp. 14-22.

Shchuplenkov, O.V., Shchuplenkov, N.O. 2013. Problemy vzaimodejstvija grazhdanskogo obshhestva i gosudarstva v sovremennoj Rossii. Juridicheskie issledovanija 4. DOI: https://doi.org/10.7256/2305-9699.2013.4.585,http://e-notabene.ru/lr/article_585.html (accessed 30.10.2018)

Shekova, E.L. 2003. Jekonomika i menedzhment nekommercheskih organizacij. Uchebnoe posobie. Sankt Peterburg: Izdatel'stvo "Lan".

Shekova, E.L. 2014. Uppavlenie uchrezhdenijami kul'tury v sovremennyh uslovijah. Uchebnoe posobie. Sankt Peterburg: Izdatel'stvo "Lan", Izdatel'stvo "Planeta muzyki".

Siellawa-Kolbowska, K.E. 2002. Niezależne inicjatywy społeczne w Polsce końca lat osiemdziesiątych. In: P. Gliński, B. Lewenstein, A. Siciński (eds.). Samoorganizacja społeczeństwa polskiego. Trzeci sektor. Warszawa: Wydawnictwo IFiS PAN. 
Smorgunov, L. (ed.). 2018. Publichnaja politika. Instituty, cifrovanie, razvitie. Moskva: Izdatel'stvo "Aspekt Press".

Sojuz blagotvoritel'nyh organizacij Rossii (SBOR). The Union of Charitable Organisations of Russia, http://www.sbornet.ru/sbor/missija_celi_zadachi (accessed 29.11.2018).

Solov'ev, A.I. 2018. Publichnaja politika i prinjatie gosudarstvennyh (politicheskih) reshenij. In: L.V. Smorgunov (ed.). Publichnaja politika. Instituty, cifrovanie, razvitie. Moskva: Izdatel'stvo "Aspekt Press".

SPb centr ,,Strategija”, http://strategy-spb.ru/ (accessed 31.12.2018).

Sungurov, A.Ju. 2008. Grazhdanskoe obshhestvo i ego razvitie v Rossii. Uchebnoe posobie. Sankt Peterburg: Izdatel'stvo "Jutas".

Sungurov, A.Ju. 2017. Publichnaja politika. Osnovnye napravlenija issledovanij (mirovoj i rossijskij opyt). Publichnaja politika 1, pp. 8-28.

Sungurov, A.Ju. (ed.). 2002a. ,Fabriki mysli” i centry publichnoj politiki. Mezhdunarodnyj i pervyj rossijskij opyt. Sbornik statej. Sankt Peterburg: Norma.

Sungurov, A.Ju. (ed.). 2002b. Komissii i Upolnomochennye po pravam cheloveka. Opyt rossijskih regionov. Sankt Peterburg: Norma.

Svod zakonov Rossijskoj imperii. Tom desjatyj. Chast' I. Zakony grazhdanskie, Tipografija II otdelenija Sobstvennoj Ego Imperatorskogo Velichestva kanceljarii. 1857. Sankt Peterburg, https://www.runivers.ru/upload/iblock/3b1/10-1.pdf (accessed 30.10.2018).

Sztompka, P. 2012. Socjologia. Analiza społeczeństwa. Kraków: Wydawnictwo Znak.

Tarasenko, A.V. 2015. Nekommercheskij sektor v stranah Evropejskogo Sojuza i Rossii v kontekste transformacii gosudarstva blagosostojanija. Sankt Peterburg: Norma.

Timofeev, N.S., Gogolev, P.V. 2012. TOS i obshhiny korennyh malochislennyh narodov Severa v sisteme mestnogo samoupravlenija Rossii. In: V.I. Fadeev (ed.). Sbornik statej, posvjashhennyh 75-letiju so dnja rozhdenija akademika O.E. Kutafina. Moskva: Izdatel'stvo Jelit.

Truex, R. 2014. The Returns to Office in a „Rubber Stamp” Parliament. American Political Science Review 108(2). DOI: https://doi.org/10.1017/S0003055414000112

Tul'chinskij, G L., Shekova, E.L. 2009. Menedzhment v sfere kul'tury. Uchebnoe posobie. Sankt Peterburg: Izdatel'stvo "Lan", Izdatel'stvo "Planeta muzyki".

"Ugolovno-ispolnitel'nyj kodeks Rossijskoj Federacii" ot 8.01.1997 g. \# 1-FZ (red. ot 20.12.2017), http://uikod.ru/ (accessed 31.10.2018).

Ukaz Prezidenta RF “Voprosy Ministerstva justicii Rossijskoj Federacii” ot 13.10.2004 g. \# 1313 (red. ot 24.10.2018), http://www.consultant.ru/document/cons_doc_ LAW_49892/ (accessed 31.10.2018).

Ukaz Prezidenta Rossijskoj Federacii “O dopolnitel'nyh merah po podderzhke obshheobrazovatel'nyh uchrezhdenij v Rossijskoj Federacii" ot 31.08.1999 g. \# 1134, http:// www.kremlin.ru/acts/bank/14338 (accessed 7.11.2018).

Ukaz Prezidenta Rossijskoj Federacii “O strategii nacional'noj bezopasnosti Rossijskoj Federacii do 2020 goda” ot 12 maja 2009 g. \# 537. Rossijskaja gazeta. Federal'nyj vypusk 2009. \# 4912 (88), https://rg.ru/2009/05/19/strategia-dok.html (accessed 30.10.2018).

Ukazanie Banka Rossii "O porjadke vedenija kassovyh operacij juridicheskimi licami $i$ uproshhennom porjadke vedenija kassovyh operacij individual'nymi predprinimateljami i sub'ektami malogo predprinimatel'stva" ot 11.03.2014 g. \# 3210-U 
(red. ot 19.06.2017) (Zaregistrirovano v Minjuste Rossii 23.05.2014 g. \# 32404), http://www.consultant.ru/document/cons_doc_LAW_163618/(accessed 8.11.2018).

Wierzchosławski, R.P. 2006. Politeizm aksjologiczny, władza ekspertów a wolność obywateli. Kilka uwag o meandrach wiedzy, władzy i republice. In: A. Gawkowska, P. Gliński, A. Kościański A. (eds.). Teorie wspólnotowe a praktyka społeczna. Obywatelskość, polityka, lokalność. Warszawa: Wydawnictwo IFiS PAN.

Wygnański, J., Gumkowska, M. 2005. Modele III Sektora w Europie. In: A. Gałązka (ed.). Elementarz trzeciego sektora. Warszawa: Stowarzyszenie Klon/Jawor.

Zakljuchenie na proekt federal'nogo zakona "O vnesenii izmenenij v nekotorye zako-nodatel'nye akty Rossijskoj Federacii" \# 233364-4, prinjatogo Gosudarstvennoj Dumoj Federal'nogo Sobranija RF v tret'em chtenii 23.122005 g., http://www..owl.ru/texts/ expertis_III_proekt_FZ-233364-4.doc (accessed 30.10.2018).

Zakon RF "O potrebitel'skoj kooperacii (potrebitel'skih obshhestvah, ih sojuzah) $v$ Rossijskoj Federacii" ot 19.06.1992 g. \# 3085-1 (red. ot 2.07.2013), http://www. consultant.ru/document/cons_doc_LAW_608/(accessed 4.09.2018). 